Published as:

Barazangi, Nimat Hafez. The Equilibrium of Islamic Education: Has Muslim Women's Education Preserved the Religion? Religion And Education, 25, 1 \& 2, (Winter 1998), 5-19.

\title{
THE EQUILIBRIUM OF ISLAMIC EDUCATION: HAS MUSLIM WOMEN'S EDUCATION PRESERVED THE RELIGION? ${ }^{\mathrm{i}}$
}

\author{
Nimat Hafez Barazangi
}

\section{SUMMARY}

I focus on issues of equilibrium in Muslim women's education to understand the tension between the ideals and practice and its ramifications for Islamic and Muslims' education in the United States. ${ }^{\text {ii }}$ I argue that one maintainer of Muslim women's low effectiveness, perpetuated across new generations of Muslims, is the general perception that women are the preservers of culture and religion by proxy. The issue before us: How is it possible for a morally dependent individual to instill the character of autonomous spiritual and intellectual Muslim who can integrate ${ }^{\mathrm{iii}}$ effectively in a "pluralistic" society?

In addition to the various degrees of perceptions and misconceptions about Islam, religious tolerance and Multiculturalism, the problem is mainly of perceiving women, particularly Muslim women as morally dependent and, hence, socially and politically irrelevant or non-central to issues of Islamic education. With the exception of few, the majority of Muslim women are neither involved in the educational decsion-making of the Muslim community nor of this nation. Often perceived as preservers of customary practices instead of agents of cultural change and contributors to inter-cultural understanding, Muslim women and their Islamic higher learning has been marginalized.

\section{INTRODUCTION AND BACKGROUND}

To fulfill the purpose of human existence as the trustee of God (Qur'an 2:30), a Muslim must at least be acquainted with the Islamic system and its methodologies 
(Barazangi, 1996: 91-92) before she or he can turn the article of faith (There is no divinity but God) into action. Understanding Islamic worldview, is as simple as the ability to recite and know the meaning of the article of faith stripped of the many layers of translations and meanings that over time have added gender-, class-, ethnic-, or other biases. This does not imply to be cut off from previous knowledge and heritage, but to keep them in their proper place as secondary sources. The issue of Muslim women's Islamic higher learning, and participation in the interpretation of the texts and in decsionmaking, therefore, is allowing the Qur' an to speak for itself to the individual woman, to be a person's guide. (Barazangi, 1997, forthcoming)

Educators, such as Lickona (1997) and Allan Lockwood (1997) are directing their attention to virtue and character education, respectively. What used to be the focus in the 1970s and 1980s of moral and value clarification education is now taking new form and label. Others, like Anderson, et al. (1997: 333-364) are investigating citizenship education. Addressing what Anne Turnbaugh Lockwood (1997) calls "troubled times," others are discussing religious education as either troubling or necessary phenomenon. Gaddy, et al. (1996) call their collection "school wars over religion and values." William J. Bennett (1992) talks about the fight for "our culture and our children." A third, and similar trend is forming within the fields of history and cultural studies. Hollinger $(1997,1996)$ is moving the "ethno-racial diversity" debate to the "postracial, the religious" debate. Glazer (1997) is accepting that "we are all Multiculturalists," and in (1997a) discusses religious conservatism and American diversity. To my knowledge, few views of Muslim educators are expressed within the "mainstream" educational literature iv Why?

In this chapter, I suggest that a transformation in the framework of investigating moral, character, or religious curricula is needed if we are to observe a significant change resulting from the contemporary "educational reform" movements. As issues of character building and religious identity are making a visible dent both within educational assessments and religio-ethnic cultural studies, I concern myself with the cross-cultural understanding of what we mean by any type of education that takes religion, value, character, moral or any other similar term as a sub-text. As evidence, I present a case-in- 
point : "Islamic education," and Muslim and non-Muslim educators' perceptions concerning the education of Muslim women and its subsequent effect on the education of American Muslim girls and of Muslim youth, in general.

Though the claim is often made for the need to discuss the framework of multiethnic, multi-religious curricula, a predominant interpretation of Islam, Muslims and Islamic education, I argue, might have shaped the character of the young Muslim girls living in the United States. As these girls marry and take on the role of women, their perceived limited role is perpetuated through the next generations. While females represent the majority of practicing educators, the dominantion of Muslim male's interpretation of "Islamic education" and decision-making in "Islamic schools" (and other formal and informal educational settings) advocate the perception that females are the preservers of Islamic culture and Islamic religion, and need different, separate education from that of males. ${ }^{v}$ In addition, when issues of religious vs. public schools are discussed, they are mainly discussed in popular Muslim culture magazines and the focus is often on the female corruption by sexual promiscuity, co-education, teenage pregnancy, et. Muslim parents and educators do not see the need for each individual -male or female--to translate Qur'anic principles into new practices. As women generally rely on others' interpretations, they are seen mainly as preserving stall applications of Islam from another context, instead of being educated to become involved in the understanding of the Deen (Arabic equivelent of Islamic worldview and way of life, including religion) in the new context. Despite their claim of a different philosophy of education--the philosophy that is rooted in the ideals of Islam--Muslim educators do not differ in their perception of females' education and role-modeling from the general view that school environment is "a place where the knowledge, historical perspectives and values that are basic for our culture [in the US] are passed from one generation to the next." (Gaddy, et al. 1996: xi) The difference is a difference in the nature and content of the values, or so it seems, that each group appears to propagate. ${ }^{\mathrm{vi}}$

By introducing gender as another factor of "diversity" beside religious values, I am shifting the focus to another level of "religious/moral" education and to another meaning of learning and construction of knowledge. I am also shifting the discussion of 
Muslim women's education from being an add-on topic to being a first priority, at the center of discussing Islamic education. I propose that without making women's Islamic higher learning (deeper knowledge of the primary sources of Islam--the Qur'an and the tradition of the Prophet of Islam, Muhammad [Peace Be Upon Him]) central to issues of Islamic education, particularly in the Western context, neither "Islamic" nor any religious or moral education will make a difference in the education of Muslims. Consequently, no other change would take place in the perception of Islam, Islamic education and Muslim's education in the "pluralistic" society of the US.

After analyzing the subtle tension of the ideals and practices concerning "Islamic education," specially that of females within the US, and the Euro-American contemporary "pluralistic" societies in general, I share a sequence of educational events with the reader. The narrative of the events may shed light on the perception of religious, moral or character education, and of Muslim woman's education in the secular humanist view of education and its ramifications for introducing religion in the curriculum of US schools. I conclude with some strategies to understand and work within this subtle tension.

The goal is to achieve an equilibrium (Taqwa) or the balance between the individual--with the ability to choose in order to live out the "trust" God has given to human beings, women and men--and the limits of the society on Muslim females' Islamic higher learning. ${ }^{\text {vii }}$ Muslim women are still viewed as dependent mothers, daughters, sisters, and as wives, but rarely as having an autonomous trusteeship in line with the Qur'anic intntion of vicegerency (al-Khilafa) (2:30). This perception contadicts the Qur'anic worldview that deciphering the signs (ayat) of the Qur'an is endowed in the human existence. (Rahman, 1980:1) In addition, as Taqwa is often translated only as piety in relation to God, the human imediate expreience of the Qur'anic signs is compromised by the intermediary of such translations and interpretations. Taqwa is both a goal and a means to the equilibrium of Islamic education (referred to in the Qur'an $[3: 110]$ as the process of shaping one's character within the Islamic worldview) within a particular context. ${ }^{\text {viii }}$ My assumption is that the Islamic principle of Taqwa, as Rahman explains, refers to human conscientious balance between individual and social needs, 
guided by the limits set forth by God and is the only criteria in judging the success or failure of Islamic education, as much as it is the only criteria of differentiation between individuals (the best among you is the balanced one, Qura'n 49:13). The purpose of the Qur' an is not to propagate a theology of God, nor a philosophy of reason and revelation, as Lickona suggests, but mainly to present a pedagogical guidelines for human constructive interaction with others .

\section{PLURALISM, SECULARISM, AND THE EQUILIBRIUM CURRICULUM}

Robert L. Gulick, Jr. wrote in his book Muhammad the Educator (1953): The title of this study, Muhammad the Educator, assumes that Muhammad is entitled to a place in the ranks of those who have influenced the educational and cultural progress of the human race. Is Muhammad usually so regarded and is the assumption justifiable? Does religious feeling becloud the vision of investigators? It is doubtless true that Muhammad is seldom regarded as an educator and this fact largely accounts for the unwillingness of reputable scholars in the English-speaking world to design to write his biography from a pedagogical standpoint. It seems at first glance incredible that an unlettered man should be hailed as an educational leader. Muhammad said that the Qur'an [transliterated in older English texts with a ' $k$ ', 'Koran,'] was his only miracle, it being the revelation of an untutored mind and the first book in Arabic.

The Qur'an also describes Muhammad as: "thou (stands) on an exalted standard of character." (68:4) Gulick goes on to say: I believe "that only the most provincial concept of education would gainsay the legitimacy of placing Muhammad among the great educators of all times for, from the pragmatic standpoint, he who elevates human behavior is a prince among educators" (p 4).

Quoting Gulick was not meant to imply that the importance of Islamic culture and religion in the development of contemporary civilization has been wholly ignored, though the debate is possible. My intention is to focus on the importance of relating between tow domains in the pedagogy of moral judgment and religious education, 
particularly in "pluralistic" societies like the US: The ontological domain (the beliefs about the nature of reality) and the intellectual domain (the causal and associational standards by which we investigate reality). This relation between the two domains is rarely discussed in contemporary educational debates (for example, views on reason and revelation in Baier, 1997:65-76) and are almost absent from American Muslim educators' discussions. Perhaps central to this abscence is the general Muslims' perception that by merely imulating the Prohpet's behavior literally, they would impart "the best of character" onto their children, irrespect of time and place.

As a Muslim female, a researcher and educator in Islamic and Arabic studies in the multi-cultural, multi-religious setting of the US, and as a parent I am confronted by a constellation of challenges involving three related tasks. My first task is to respond to the debate of pluralism, secularism, and the preservation of the individual beliefs within a seemingly secular educational system in the US. Though Nord argues that modern education is intended to secularize the Western society, one needs only to see the explosion of literature on religion and education in the last decade and Nord's title "Rethinking a National Dilemma" to realize that US education system was not secularized, but dichotomized or privatized. It might have been modernized, "De-Christianized" as Hollinger (1996) points out, but religion is still the foundation philosophy of education since religion has been part of the education process since the establishement of public schools in 1647. ${ }^{\text {ix }}$ Perhaps the manifestations of this philosophy and the standards by which educational ethics are being measured have varied.

My second task is to maintain a level of research standards that are based on the Euro-American modernized views of life and education, but within a worldview that is embedded in the Islamic view of reality in order to make it accessible to the readers who are un-familiar with the basic Islamic philosophy.

My third task is to design an integrative curriculum for subject matter that is rooted in the principles of no separation between human belief, morality, and knowledge-the Islamic view as stated in the Qur'anic and other scriptural messages. This integrative curriculum poses very important questions to the present Muslim girls'education, even though it--the curriculum--is not limited for the education of Muslim women nor to Muslims living in the US. Given that its first condition for constructive thinking is 
similar to that of Islam : autonomy in seeing the signs of ones's belief system, and acting on them, does not mean that this curriculum is exclusive to females or to Muslims. Yet, the realities of teaching about, and practicing Islam have caused Muslim girls to wonder about their own belief system. Faithful as they may be, the first questions in their mind are: "Why can't a Muslim woman be part of the decision-making ? How could we follow the example of Muhammad when some Muslim men discredit our presence in the mosque as unlawful?"

As I have explained elsewhere (Barazangi, 1997), the reason why these girls ask such questions is because they have not had direct deep contact with the basic principles of Islam, nor had they been able to relate the sacred word and text with daily life. A Muslim girl who, for example, recites the verses "In the name of Allah, Guardian of the World, the Merciful, the Magnificent" (Qur'an, 1:1-2) tens of times in daily prayers without relating to their significance as defining the human relationship to God, to others, and to nature may not be able to realize herself as a Muslim. I have also argued that because women were prevented from direct involvement in Qur'anic sciences--not only memorization-- they are in effect not practicing Islam as a pedagogical system of the trusteeship.

The belief in the Prophet Muhammad is further troubled by the fact that the prophet is a man. The difficulty to separate Muhammad the prophet from Muhammad the man may have resulted in cognitive dissonance. Though the confusion seems to exist in the minds of most contemporary Muslims because of the idealization of many figures over the centuries --despite the Islamic message to denounce human idealization--, it is a more acute problem for women because the suppression of their Muslim identity is due to the claim of male superiority and guardianship. Idealization of male authority prevents living one's trusteeship fully.

A multicultural, pluralistic curriculum that develops the integrated, constructive, equilibrated character in the learner is a rigorous and time-consuming process of conceptual and attitudinal change for researchers, instructors, students, and parents alike. But as long as such a curriculum claims to utilize pluralism with secularism as the only 
value base, the above visions may not be completely fulfilled. Similarly, as long as Muslim educators claim to impart "Islamic" character with women's morality is seen as a proxy to that of her male household, the human trusteeship may no be fulfilled, nor would Islamic pedagogy be actualized. Realizing the absence of deeper understanding of pluralism and of secularism, including the religious philosophical foundations (see Nord's argument for understanding the absence of religion from modern American education, 1995:15) and the secular humanistic view of curriculum development, is critical to educating and learning in the multireligo-ethnic setting. Nonetheless, recently and more frequently, we are faced with problems resulting from the use or misuse of pluralism and its concomitant principle, individual right to freedom of expression. ${ }^{\mathrm{x}}$ These problems call for deeper synthesis of the concepts of pluralism and of egalitarian, secular education, and of religous education.

Pluralism, the private and public domains: Pluralism has been implicitly taught as the value gained by the political ideology represented in the separation of the public affairs from the particular, "private" belief system of a group or individuals who share one belief system. (Arjomand, 1993:4) This separation is called secularism. Plurality, therefore and in essence, can be understood as the antithesis of individuality or private values that govern the individual belief system and its application in both private and public affairs. The makers of the United States Constitution, we are told, have thought that the means by which a pluralistic governing ideology can be established is through secularism. In other words, by taking away the right to govern from a particular religious conviction (represented at the time by the singular theocratic institution of the church), secularity was thought of as a facilitator of the pluralistic governing body.

Actually, what seems to have happened was that the individual freedom of belief and choice of a religious affiliation, which forms the basis of the separation of the normative order -- a private belief system-- from the governing order--a public political system, was sacrificed for the sake of secular plurality (see Arjomand discussion of the relationship between religion and politics). In this context, social scientists and educators--including Muslim educators--adopted the view that envision society as a collection of self-regarding, independent agents, but not necessarily as self-regulating 
morally autonomous agents, as Piaget's social theory explains and as the Islamic principle of Taqwa is intended for. As William Sullivan (1982:10-19) explains: "the liberalist themes of defense of freedom for the individual form the basis of our separation of public and private realms of discourse and activity." I may add, the secular humanist view of education and of other disciplines went farther in its demand for this separation to the point of separating between normative and "scientific" discourses or between human belief and knowledge, instead of separating the normative orders from their heteronomous morality represented in social egalitarianism, with a consequence of neglecting cognitive egalitarianism. That is, individuals may behave socially as though all humans are equal and may present convincing (to the converted) evidence, but deep in their minds and hearts a dissonance thrives between their belief of the "transcendent truth" and their views of reality. This is evidenced in the repeated bigoted remarks against other religious beliefs in the plural society of America, such as the recent remark by Dr. Jordan, a member of the South Carolina State Board of Education. ${ }^{\text {xi }}$

Arjomand expresses this situation in the context of religion, order, and pluralism as follows: "The world religions have had to face the competition not only of philosophy but also of the survivals of pre-Axial Age normative orders. These competing 'secular' normative orders progressively narrowed the sphere of religion in the course of history. This process of secularization has gone further in the West, and has resulted in considerable "privatization" of religion. But it would be a grave mistake to assume, as is commonly done, that the pluralism of normative orders is the exclusive characteristic of the modern West." Not only do our political cultures contain multiple truths that make normative diversity their distinct, albeit unacknowledged feature, Arjomand goes on to say, but the public representation of the transcendent truth--as a cultural-specific feature-itself is a matter of contention within each religio-cultural tradition. ${ }^{\text {xii }}$

Secularism, the normative and scientific discourses: The first consequence of social egalitarianism and of the separation of the 'normative' from the 'scientific' is that educators ignored the fact that even scientific discourse (i.e., to describe, explain, or understand a phenomenon) forms a philosophical commitment that controls the way inquiry is conducted and determine the significance that the resulting knowledge will 
have (Shapiro 1981:3). A good example of this consequence is the repeated misuse of what is known as "common-sense morality." Offenders seem to have lost touch with this common -sense morality because they have lost the thread that once held together the meanings of a moral act. By separating the normative and scientific discourses, it is more likely that one may not understand the relationship between private discourse (the spiritual, the affective and the cognitive) and public discourse (the social and the political). As a result, the moral grounds to which individuals used to be held accountable --the ethical conduct both publicly and in private--are also lost because the relations between the public and the private was severed.

The second consequence of the separation between the normative and the scientific is that a decision maker (whether a young college student, a curriculum specialist, or a president of a university), is implicitly expected to decline his or her inherent rights to freely express his or her own beliefs because she is told that this is a private discourse --that underlies his or her character and philosophical commitment--and has no part of the public discourse. Instead of actively dialoguing about one's own beliefs, the social pressure to decline or suppress one's views triggers, unknowingly, descention against one's own beliefs or against the "others" " philosophical or religious convictions, specially if left untreated. This suppression often takes on the form of a backlash view or policies, such as the case among the "religious right" movement (Gaddy, et al., 1996), but more damaging is the individual learners' perception of the system.

The third and the more damaging consequence, is that the individual and private realms of discourse seem to be free on the surface through some forms of individualistic expression. Yet in actuality pluralistic secularists have, perhaps unknowingly, created beneath the surface a fermented conceptual conflict within the individual. This conceptual conflict, cognitive dissonance, resulted in the majority of cases in a form of disequilibrium between the private belief system and the public political domain. Thus, what has been thought of as socially constructed minorities are actually a majority of socailly assimilating and conceptually accommodating but morally heteronomous groups of people. In addition, what has been thought of as majority "mainstream" values are 
socially assimilated, exploited values by some public agents instead of being a base of conflict-resolution activities for cognitive egalitarianism and moral autonomy.

The overall consequence is a surge of individualism that cannot be contained by its own belief and value system either. The antagonistic racial and sexist irresponsible surge of actions on school grounds and at the college campuses present more than just behavioral problems to educators. They are forcing everyone to look back at the ethical questions as a refuge. But, unless these challenges are dealt with by a deep understanding of the multicultural nature (i.e., the diverse views on the nature of reality and its relation to perceiving "scientific" facts) of the students and teachers, all solutions will be only temporary at best.

\section{IS THERE AN ALTERNATIVE?}

Yes, by giving back to humans their true right, the true expression of their moral, private existence--whose goals are intricately interrelated with the goals of the communities to which they belong--in an integrated manner with the public existence. As educators and policymakers we may be able to perpetuate the chance for true tolerance to grow by allowing the re-unification of human belief system with its moral and political action in an equilibrium. We can replace the instrumental moral and political outlook by a concern for the ethical quality of social relationships, shared initiative, and moral responsibility. To be a conscientious being both in thought and in action, the Qur'an tells us, is to follow the natural pattern in which humans were created (30:20), the pattern in which humans actualize the "Divine Will" through their own will and action. To the contrary, as long as we expect individuals to separate their belief from their political action, duality in action and, what I would like to call, window-dressing pluralism will prevail more and more. Through a process of understanding and application of an integrative belief and action, the practice of multicultural design will go beyond the form of aggregated private opinions into a "common-grounds," and will be expanded to include a search for shared meanings .

The advantage of such an integrative curriculum is that it will not take away, like the liberalist tradition did--perhaps unintentionally, from the communities of individuals the ability and the desire to deal with their own problems. Such a curriculum will realize 
the complex relations among private and public discourse in a social and educational programs instead of merely gather and use scattered techniques and information. Finally, the question of what image of human nature and society should guide our practice can be answered simply by examining our given premise and its results. By examining pluralism and its principles of secularism and individualism, we realize that they are no longer a source of an adequate moral image of human nature. Thus, investigating and understanding each other's belief systems and views of reality might be the first step toward cognitive egalitarianism.

Let us, for instance, examine the premise of the need for a metaphysical belief for a multicultural, pluralistic curriculum from the Islamic point-of-view. Fazlur Rahman wrote in the answer to "Why God at all?": " The Qur'an calls this 'belief in and awareness of the unseen,' this 'unseen' has been, to a greater or lesser extent, made seen through Revelation for some people like the Prophets, although it cannot be fully known to anyone except God. God's existence can, however, be brought home to those who care to reflect so that it not only ceases to be an 'irrational' or 'unreasonable' belief but becomes 'the Master-Truth.' This is the task of the Qur'an: if the task is accomplished, everything has been accomplished; if not, nothing whatever has been achieved." (1980:2)

Rahman goes on to say that in order to achieve this, students must do something; if they do not, they cannot be called students at all. It is therefore, not an extraordinary or an unreasonable demand. The student must "listen" to what the Qur'an has to say: "Who is humble before the unseen and brings with him [ or her] a heart such that it can respond [when the truth hits it]" (50:33).

The problem, Rahman laments, is not how to make [hu]man come to belief by giving lengthy and intricate "theological proofs of God's existence, but how to shake him [or her] into belief by drawing his [her] attention to certain obvious facts and turning these facts into 'reminders' of God. Hence, the Qur'an time and again calls itself (and also the Prophet Muhammad) 'a reminder' or 'The Reminder'." The Qur'an, I must add, calls all the prophets and apostles as those who posses the (reminding) message (11: 7), and that the "master truth" may not be known without the human intimate knowledge (7:33). 
Rahman concludes: Once a learner have grasped these [the above] points, s/he will have understood the absolute centrality of God in the entire system of existence, to a very large extent because the aim of the Qur'an is the human and his/her behavior, not God.

\section{THE CASE-IN-POINT: THE EVENTS}

Several events happened, beginning in the late 1980s and as I was working on my docterate research project on Muslim's perception of the Islamic belief system. These events have occupied my thinking during the last decade, triggering my long-term research in the education of Muslim women.

\section{The 1980's Event}

A sixteen-year old second-generation Muslim of immigrant Muslim parents had received a very high mark in a quiz on the Advanced Placement Physics course that she was taking at the High School. Her teacher was so thrilled to the point that he told the entire class about it, lamenting that in his thirty years of teaching this was the second student who obtained such a high grade. What created a problem, according to the 16 year-old, is that some of her answers were not the result of her own guesswork, as the teacher commented later. She felt that she did not really deserve all that praise but she could not tell the teacher immediately that some of the answers were written on her test book (to be explained later) because she was afraid to disappoint him at his state of joy and exhilaration. What complicated the matter further is that even when she told her mother about the incident she did not tell her mother the full truth at the time either.

Analyzing and reflecting on such events has guided my thinking and action about multicultural education, and might be instructive for other educators in Islamic and pluralistic educational issues. Whether the principles that underlie such events are taken-

for-granted by American Muslim parents and educators, or are not of a major concern to American educators and policymakers, in general, is not the focus of our discussion here. ${ }^{\text {xiii }}$ The focus is the pedagogical implications of the event.

As other events unfold in the development of the same female Muslim student almost ten years later, in the 1990s when she became a young adult, I take note and 
transform my own thinking about imparting "Islamic education." The main question I am asking now: “Have the mother's 'Western' higher education and 'Islamic religious knowledge' helped her preserve the Islamic religion in the US?" This transformation in my thinking has guided my recent presuppositions about Muslim women's education both in the multi-religious, "Western" and the "Muslim" contexts.

In analyzing the 1980s event, it seems as if the daughter had developed, as Piaget explains, a self-regulated morality, but has not yet grew completely free of the others' moral regulation. ${ }^{\mathrm{xv}}$ She seems to have understood the "matter of course" of the US educational system and the scholastic achievement as an essential part of academic validation. Although she was able to maintain her own regulation (validation) of honesty irrespective of others' knowledge of the truth of the matter, she did not seem to understand the meaning of expressing her own values as separate from the generally practiced norms of "honesty." Nor did she seem to realize the relationship between the "mainstream" idealistic perspective of "plurality" and the realistic demands of the pluralistic society.

This blurry relation between her values as an individual Muslim and the social regulations of conformity whether in public schools or among Muslims, I argue, is the result of the general perception that religious and moral values can be inculcated in the child merely by providing a role model in the immediate environment of the child. The mother, as the role model, though was aware of the discrepancy of the home and the social environment, was not aware at the time that the duality in instructing about the Islamic ideals without clearly relating these ideals to daily life at home and in school was creating a gap in her daughter's schema of knowledge and value. In addition, some of the mother's practices--the customary practices in her native Muslim society--had no relation to the child environment, the environment of the mainstream society.

As I wrote earlier (1995:406), resulting from dualism in education--secular modern vs. religious traditional--that was introduced to Muslims through European colonial and missionary work, Muslim practices have "transformed the Qur' anic pedagogy from understanding and acting on "the parameters set in the Qur'an for a constructive relationships" into a list of "Islamic" vs. non-Islamic" do's and don'ts 
practices. Compounded with males' perception of women's moral dependency--contrary to the Islamic principle of autonomous morality in which he or she is accounted for his or her own work--Muslim educators impose certain standards of behavior on girls (e.g., being bashful, wearing special customary clothing, and refraining from public interaction with the opposite sex) without requiring similar standards from males. Thinking that they were protecting the religion by instilling the habit of "female seclusion or segregation," which also reinforced the impression that raising Muslim girls ought to be totally different from raising boys, they have actually secluded the minds and souls of these girls who were the mothers/the first teachers of the future generations. Such practices were further exploited against Islam and, hence, Muslims were also stigmatized as incapable of being "rational, scientific or democratic" becasue they associate with Islam. ${ }^{\text {xvi }}$

It is obvious, as one of the Prophet Muhammad's tradition suggests (to explain below), and as Piaget's social theory informs us, that the sixteen-year old student would not have been able to make such a construction of knowledge, had she not have some elements for moral autonomoy. But why was she still troubled by her "guess work" and by the teacher's high acclamation of her? Why could she not have stood up immediately and told the teacher in front of the entire class about the "truth" of the matter?

Not only she did not inform her mother of the full truth, but neither she nor the mother or teacher were aware of the gap between the type of issues that she was dealing with vis-a'-vis the issues whith which her mother and teacher were concerned. The practical application of the "moral of the event" in the two separate environemnts--the home and the school-- with which the daughter was struggling did not register at the mother's nor the teacher's scheme of things.

When the daughter was asked at a later time, she stated that someone wrote their answers on the test book when they took the same test years before. She lamented, "because of the crabby educational system they [the public schools staff] use the same test books as from the 1950's. If I did not have a good answer, I copied their [those who used the same test book before] guess. The moral issue here, the daughter went on, you could say, is that I did not have the imagination or the will or the courage to make my 
own guess. OK, I was tired, didn't care, and just wanted to finish the exam because I knew I'd get the answers wrong anyway."

Given the general instructional and testing practices in the US educational system, the teacher seems to be mainly concerned with students understing the "science" he was teaching. High grades were the indicators of this understanding. In addition, even if students had to make a guess, he would encourage them to try and write an answer while taking the test. Obviousely, other issues involved here, but my focusing on the sixteen-year old's statement about "the moral issue here" is central in this-case-inpoint.

The mother, not knowing what the daughter has actually done or gone through then--given her lack of familiarity with the US schools instructional system, continued to think about the event, but on a different level of "morality" from that of her duaghter and the teacher. She was asking herself questions like: What made my daughter able to develop such a conscientious account of her learning experience? Is it merely her intelligence, is it her character or is it her moral/religious upbringing?"xvii More importantly, the mother kept questioning, "would my daughter have been able to develop this ability if she had not believed in the Unseen, the Supreme Guide that might have kept her conscious alive? ${ }^{\text {xiii }}$ Specifically, the mother kept wondering, "will the university to which my daughter is going be able to continue this nurturing process for such mind within its secular tradition, particularly when this girl departs from the support system she once had within her family?"

It seems as if the mother was concerned with her daughter's departing from the social regulation of "revelation" and value of the family to the social regulation of "reason" and facts that is more prevalent in the university and professional environments. Consequently, the "moral issue" for her was the daughter's loosing the practice of old customs being social or ritual values. Not realizing that these values are already blurred in the mind and soul of her daughter, the mother apparently was thinking more at the level of ideals, while the daughter was thinking more at the level of the reality of everyday matters. The mother's ability to relate between her ideals and the 
daily reality was constrained by her perception that the daughter will follow her example just as she, the mother had followed her parents' practice of ethical life.

When the mother, for example, applied the guidelines from the traditions of Prophet Muhammad concerning children moral upbringing and religious education, she was convinced that she was helping her daughter develop a well-rounded personality. The mother strognly believed that by applying "Let your children establish prayer at the age of seven, and admonish them about praying at ten," the daughter's character was shaped into the desired "Islamic personality." The mother was actually asking the wrong questions and imparting the wrong meaning of "Islamic education." By not realizing that her mere emulation of the models without understanding the principles behind them nor the environment in which they are to be applied, she was assuming that morality develops only by emulation of societal norms. This kind of morality-- that piaget calls a heternomous morality in which children are asked to conform to certain practices without giving them the chance to internalize the principles behind these practices-- contradicts the basic Islamic principle of autonomous morality that allows the individual to carry-on the role of trusteeship. Trusteeship means that a prerequisite to identification with Islam, the individual has an immediate expereicne with the Qur'an/ Islamic worldview (wanting to listen, as Rahman stated above) in order to apply the scheme of value and knowledge constructively within a particular time and place.

I argue, therefore, that the mother's ability to help her daughter make a connection between "facts" and "values" was mainly a result of the self-learning and self-construction of both. Yet, not reaching the understanding of self-realization as an autonomous trustee--that is, not realizing that the Qur'an mandates access to and acquistion of deeper knowledge of religious sources in order to live out the "trust", the mother's self-identity with Islam was not realized. In other words, not being able to draw the relationship between her practice of Islam and the principles underlying her value system (the totality of her worldview of Islam as a belief system) the mother was not able to affect a change in her own perspective and understanding of "Islamic education."

Educational Implications of the event: Today's educators need to ask: "How does the learners's immediate experience with the curricula affect their character development?" 
instead of "How many high school graduates are being equipped with character education?"xix If one assumes that conscientious, constructive learning experience is the type of education that we, American educators, value, then the question is "how can this process of character development be replicated in time and place" instead of "how can the development of such a character be replicated $?^{\mathrm{xx}}$

How can these elements that formed the whole of such a person who minifested socially "desired" character be found in a system that for many decades has overlooked the underlying principles of human moral development? as Lickona suggests . The secular humanist system ignored, for instance, the other part of the constitution that talks about being literate in religion. (Lickona, 1997: p 28) More importantly, the system does not seem to be concerned that "secularization" actually resulted in the separation of moral and cognitive development, contrary to what Piaget 's social theory emphasizes when discussing their relationship. (DeVreis, 1997:4) How, then, do proponents of $\underline{\text { religious education expect to nurture this relationship between moral and cognitive }}$ development within this same secular humanistic worldview of education? Is it enough to just raise the flag of the importance of teaching religion in schools to preserve "our culture and our children" as Bennet (1992) suggest--whether teaching about religion as the document on Religion in the Public School Curriculum suggests, ${ }^{x x i}$ or teaching of religion as a subject in private Islamic or parochial schools? What is needed is a change in our perception of how to design a curriculum that facilitates for learners an awareness of the relationship between their own moral and cognitive development within the "pluralistic" educational system. That is, unless we recognize that this relationship may not become Islamic, for example, without the individual Muslim herself consciously makes sense of her own identification with Islam and within the realities of place and time, neither public nor parochial will help the process of constructive character building.

The second question before us, is "how many curricula of pre- or post-secondary education concern themselves with such relations between reality (s) and principles? Can we teach these skills within our present philosophy of education?"

Though I am discussing the case of a Muslim young female and her mother, I am not only pegging the question of Islamic identity here. ${ }^{x x i i}$ The issue of connecting, or the lack of, ideals to realities and cognitive to moral development are not limited to 
Muslims. Muslim girls, for instance, often being discriminatorally prevented by their parents from co-ed physical education and other social activities with the execuse of modesty, while their brothers often left to participate in similar activities. These practices makes them (the Muslim girls) wonder as to whether or not they want to identify with Islam. Similar discrimanatory practices and perceptions concerning girls and women's "pluralistic," universal schooling and the role of women's liberation movement in contemporary societal upheavals are also of concern. The issue concerns all religious and non-religious groups who are consciously attempting to impart a special value system instead of attempting to understand the depth of the problems that today's young girls of the pluralistic society are facing. Allan Lockwood, for instance, argues that it is a matter of change in perspective of what is moral and what is accepted socially. Though I may disagree with Lockwood's relativism, I do agree with the idea of a change in perspective. That is, what we now see as "troubled times" are only the symptoms of a deeper problem, namely, not realizing the pre-requisit of moral autonomy in the connection between cognitive and moral development.

What makes the event in this case study an issue of Islamic education in the United States, therefore, is its absence from a pro-active debate among American Muslim parents and educators, and between them and American educators in general. Instead, Muslim parents and educators' often react to the symptoms, other events-- such as not allowing girls to wear head-cover in schools. They often join the "mainstream" media and educational and political decision-makers in the one-sided, shallow analysis of these symtoms that has dominated these debates as well as the discussions of diversity issues in education. I would rather ask the question that might lead us to a dialogue: "What issues are we debating? and how do we expect to agree, even on a common ground when our philosophy of knowledge (epistemology) and understanding of reality (ontology) differ among us and between us, educators, and decisionmakers?" Is there an alternative to insisting on a common ground, and in whose interest are we debating, ours, the policymakers' or the learners'? When will it be possible for us to realize that learners develop an effective way of knowing when they develop an autonomous, instead of a heteronomous morality? (The Qur'an, 2:256; and Piaget, 1950/1995 as quoted by DeVries, 1997) The autonomous morality will by itself manifest the values that we are 
trying to instill. Whether these values are "neutrally" moral or religious-specific, the person herself will determine, once she becomes aware of her own spiritual, moral and intellectual autonomy. ${ }^{\text {xiii }}$ Thus, a Muslim's faith in Islam will develop only when the person realizes the meaning of human trusteeship as an individual responsibility, be it a male or female. Only then, would the Islamic principle of Taqwa (equilibrium) be fulfilled, and Islamic education be achieved.

Why are these questions more relevant to Women's education: One might respond to all of the above questions by saying that these issues are not unique to girls, let alone to Muslim girls. This might be true if we have an equitable, and integrated perception of what it means to access the same levels and meanings of learning for the cultural groups that constitute today's American young Muslim girls. The reality is that this is not the case, particularly when general sources about Islam and Muslims, including textbooks and major books on religion and education, still use biased views to describe or compare Islam $^{\mathrm{xxiv}}$ or to describe Muslim females and their need. ${ }^{\mathrm{xxv}}$ Furthermore, the manner in which Islam and Muslims are being perceived complicates matters more. ${ }^{\mathrm{xxi}}$

The uniqueness of this case lies in the apparent pride that the sixteen-year old girl takes in her identity despite the fact that American Muslims during the 1980s and 1990s, particularly women, have been the object of derision in the eyes of many unsympathetic persons. (See Mohja Kahf's expression of these inner and external struggles in this Journal) Muslim girls and women are being margenalized by both Muslim men and none-Muslims because they are being perceived as morally dependent and, hence, educationally, politically and socially irrelevant or non-central to issues of Islamic education. ${ }^{\text {xxvii }}$ They are being used as proxies of customary "cultural" preservation in the Muslim encounter with the larger society. (Barazangi, in review) The national government and educational policy has yet to take these girls and women into account as first class citizens and agents of change--not as "others" or as second class citizens subject to change-- so that their lifestyle would not be the object of ridicule or marginalization. These women's mode of dress, for example, makes them very visible to the non-Muslims and exposes them as the more clearly identifiable target for antiMuslim 
sentiments. But Muslim males still see that these girls' and women's morality preserved in the way they dress and preserve the cutlure.

Although the sixteen-year old Muslim young girl did not experience any of the above discriminatory practices, these issues were discussed by her parents and the local Muslim community and that might have created certain awareness of them, and possibly a cognitive and moral dissonance in relation to her identity. Furthermore, both her parents seem to have overlooked the fact their daughter was trying to develop her autonomous morality through her own problematizing the 1980s event. Piaget talks about how children relate between their experience and cognitive reasoning to develop their moral judgment. But the daughter was neither fully prepared for drwaing such a relation nor has her parnets realized that. The mother did not realize this shortcoming until the onset of another event that the young female has experienced almost ten years later.

The sixteen-year old hesitation to tell the truth to her teacher and mother at the onset of the 1980's event, as reported above, is a good example of this disequilibirated cognitive and moral judgment. Her hesitation stems from the apparent clash between her respect for him as a teacher--not wanting to disappoint him at his high state of satisfaction, and as an authority figure-- and her thinking that every one's attention in the class is focused on her as a "controversial" model--having both the Islamic and the American properties. Though after dialoguing about the event with her parents she developed the confidence in her values, she was not able to expresse her normative commitment to telling the truth. The point here, is not whether the young Muslim's telling the truth is not a value of the "mainstream" ethics, nor is it that she did not tell the whole truth of the event. Rather, the point is that given the other social factors surrounding the identification with Islam and Muslims at that point of history, many Muslim young females, and males for that matter, were falling victims to the "suppressed expression" syndrome because they most likely did not have the skill of relating between the 'normative' and 'scientific.' These young Muslims of the 1980's simply were complying with the social form of egalitarianism and consequently, often were hiding their identity or margenalizing their normative differences.

\section{The 1990's Event}


when the sixteen-year old student moved out of her family's town, apparently her awareness of autonomous morality became more focused. This awareness made her at one level question the heteronomous morality that she developed while under her family support and normative system. On the other level, she began to understand the grounds on which a secular "scientific" paradigm has been built. The accepted norm in advancement of scholastic achievement demands "pure" reasoning, void of "personal" or "moral" blurriness.

Though an internal dissonance was fermenting, reaching at some point a discrete behavioral revolt, the relationship with her family seemed neutral. As the young female started 'testing the water' of complete physical, moral and emotional independence, her heteronomous morality failed her and her ability to make moral judgments for everyday personal affairs became blurry. She began experimenting with the principle of freedom of expression, but without realizing that she was actually dismantling the relationships that she once had between her values--acquired as a social norm only-- and facts-separated from values. As she put it, she started questioning the validity of the values instilled by her parents for becoming her own personal values. As the experimentation ended with some unexpected problems, the young student took on the challenge to face her parents with her inner search but with an assertive demand that she be given the chance to re-think her own life and her own ideals and action. As if she realized that the role of the "normative" system that she has inherited is inoperative in the present structure of the "scientific" secular education system that she was going through. She began the process of re-thinking the two systems.

It seems as if the young female student was equipped with some level of selfrealization. otherwise, she would not have been able to re-bound from the heteronomous morality into an autonomous morality. Irrespective of the end-result-- whether or not she will maintain the same belief system of her parents or the same standards for scholastic achievements--she will need to maintain an equilibrium of value and facts that will eventually develop into a constructive reasoning within a particular belief system in the context of the US society. As I argued elsewhere (1993), the implications of individual's ability to express her or his particular belief/value system within the multi- 
religious, multi-ethnic cultural setting is central to his or her ability to develop a constructive character. How could that be achieved is the main question before us.

\section{CONCLUSIONS AND SUMMARIES OF STRATEGIES}

The most important result and the lesson to be learned from the above events here, is that the mother had changed her thinking after 1990 event. The mother realized that her strategy for instilling "Islamic personality" in her daughter, despite all the efforts made by her and the father and despite the majority positive outcomes as the social and the parents' norms demand, was lacking an important element. She realized that she herself was imparting the value system as "a matter of course," or as the Islamic institutionalized order would have it. In other words, she was not acting autonomously despite her deep conviction about her value system, and about the importance of integrating within the pluralistic, secular system of the society.

Only when the mother regained her autonomy by re-thinking the Islamic belief system, independently of all institutionalized interpretations, was she able to become an agent of change, and eventually removed herself from being a passive preserver of a cultural heritage into an active re-interpreter of the Islamic belief system. Only then was the mother able to impart a change in her perception of Islam and was she able to build different educational strategies. That is, in a sense, being helped by the daughter's "revolt" and re-interpretation of the relationship between values and facts, the mother recognized the missing element in being a faithful Muslim: to be able to think and act autonomously irrespective of other peoples' belief and action. Now, through this renewed relationship the mother and daughter are, consciously and unconsciously, helping each other remove the blurriness about both the Islamic belief system and the American educational structure. In the process, each is attempting to recreate a more meaningful learning experience for herself and for each other in her own respective way.

In the case of young Muslim girl's education, both the premise of religious education and that of public education fail to provide the immediacy of experiencing the relationship of human value and reality. The premise of religious education and its basic principle of inculcation and exemplary models --as was the case of the mother--have raised more questions about the meaning and direct applications of values in daily life. 
The premise of public education and its basic principles--secularism and individualism-and their ramifications in the present educational system call for deeper analysis, being the value base of a pluralistic curriculum. It became clear, throughout this analysis, that this premise does not suffice for a unified human belief system with its moral and political action.

An alternative was drawn from the natural pattern of human existence, in which humans actualize the "Divine Will" through their own will and action. Even "nonbelievers" have some kind of ideal, we may call "philosophical will" that needs to be autonomously chosen, understood and connected to realities in order to be actualized. The advantage of the natural pattern is in providing an integrative curriculum that realizes the complex relations among private and public discourses in social and educational programs. Such programs enhance among the communities of individuals the ability, and the desire to deal with their own problems. Finally, the individuals' awareness and their attempt to deal with their own problems is the stepping stone towards autonomous morality and thus constructive, meaningful learning in the cognitively equilibrated egalitarianism. Muslim woman's ability to achieve such autonomous morality is the first step in this direction.

@ 1997, Nimat Hafez Barazangi 


\section{ENDNOTES}

${ }^{1}$ I would like to acknowledge Mohja Kahf and Nobl Barazangi for their invaluable insights and comments.

${ }^{2}$ See the distinction between Islamic and Muslim education in Barazangi (1995) and (1997). Islamic education, referred to in the Qur' an (3:110) as thr process of shaping character within the Islamic worldview, requires the exposition to all knowledge as a means to understanding the parameters set in the Qur'an for a constructive relationship with God, other human beings, and nature.

${ }^{3}$ Integration indicates the ability to maintain the Islamic belief system at its central level, Tawhid (Oneness of God and humanity) and to objectify it in the Western secular environment. See further explanation in Nimat Hafez Barazangi. The Education of North American Muslim Parents and Children. 1990. The American Journal of Islamic Social Sciences. vol. 7, no.3: 385-402.

${ }^{4}$ In a data-base search on Religion and education I found only six references out of 450 related to Islam, and none of them is concerned with American Muslims. There are several publications known to me as an educator, but for some reason, they are not being indexed by "mainstream" bibliography. The recent efforts of the Council on Islamic Education with regards to world history in textbooks (Teaching about Islam \& Muslims in the Public School Classroom, 1995; and Strategies and Structures for Presenting World history, 1994) are the most recognized among mainstream educators, but was not indexed either.

${ }^{5}$ See, for example, Khaliijah Mohammad Salleh. The Role of Men and Women in Society. Islamic Horizons, January/February, 1997:57.; Syed Ali Ashraf (New Horizons in Muslim Education. Cambridge Univ. Press, 1995); Anis Ahmad. 1984. Muslim Women and Higher Education: A Case for Separate Institutions for women. Islamabad, Pakistan.

${ }^{6}$ See for example, Jamila Al-Hashimi "Public School System Versus Islamic School" (Islamic Horizon, June/July 1997: 55) in which she reason that the public schools decline is the result of their attempt to make "the school increasingly the carrier of all kinds of social policies" instead of doing its job "to teach children elementary knowlesge skills". 
In the same breath, she states that "religious groups, in general, have a head start on teaching values in school." It is exactly this dichotomy in education that is creating problems in our educational system. See another type of dichoromy in R. M. Hare's (Essays on Religion and Education, oxford Univ. Press, 1992) discussion of Wilson (1964) distinction between the method and the content of education vis-a'-vis indoctrination (113-130).

${ }^{7}$ See Nimat Hafez Barazangi forthcoming "Islamic HigherLearning as a Human Right: Theory and Practice" in Gisela Webb, ed. 1998. Windows of Faith; and "Vicegerency and Gender Justice" in Barazangi, et al. eds. Islamic Identity and the Struggle for Justice. University Pres of Florida, 1996: 77-94.

${ }^{8}$ See details of the distinctions between "Islamic education," "Muslim education" and Western, secular education/universal schooling in Nimat Hafez Barazangi, 1995. "Religious Education."

${ }^{9}$ Deborah Mayo-Jefferies. 1994. Religious Freedon in the Education Process: A Research Guide to Religion in Education (1950-1992). Buffalo: William S. Hein ( ix). ${ }^{10}$ For example, the recent degrading remarks of Dr. Jordan. (see note 11)

${ }^{11}$ Dr. Jordan said in the heated argument about placing the plate of the Ten Commandments in schools: "screw the Budhists and kill the Muslims." May 12, 1997 as reproted by the Associate Press. His statement indicates exactly the point that I am emphasizing. That is, our pluralism has not become cognitively and morally autonomous. Individuals are still struggling between their normative beliefs and the "rational" presentation of others' beliefs. They have not yet come to a point where they autonomously are able to integrate the two views, or make sense of them within their own frame of reference. Whether the reason is ignorance or pure refusal to accept the other's norms is a matter for educators to assess. But the results are still strikingly suggestive that unless such individuals are able to understand and undertake cognitive egalitarism on their own, any attempt of having them accept social egalitarism will contiue to have a weak point in the system and is apt to backlash with the change of circumstances.

${ }^{12}$ Arjomand, Said Amir, ed. 1993. The Political Dimensions of Religion. State University of New york Press. (P.4) 
13 See my forthcoming article "Between the Post-ethnic and the Unique: Exclusion of American Muslim Women from Decison-Making” (in review).

14 I use "Western," "Islamic," "Muslim," "pluralistic", and other expressions in quotes because I want to draw attention to the elusiveness of these expressions, especially when contrasting "Islamic" in reference to religion vs. "Western" in reference to geogrpahy. ${ }^{1} 5$ See Rheta DeVreis. Piaget's Social Theory." Educational Researcher, vo. 26, no.2, march 1997:4-18, for further explanation of Piaget's differentiation of autonomous vs heteronomous morality.

16 Andrea Lueg. “The Perception of Islam in Western Debate.” In Jochen Hippler and Andrea Lueg, eds. 1995. The Next Threat:Western Perception of Islam. Translated by Laila Friese. Boulder: Pluto Press: 16

${ }^{17}$ Note that I intentially am using the terms "character", "moral", and "religious" upbringing interchangebly in order to bring the focus to my claim that the problem is in our framework of understanding of character, moral and religious pedagogy within the framework of "secular, pluralistic" education . I do agreee with some of the distinctions that Alan Lockwood or Lickona present, but I do no see these distinctions as the core of the problem here.

${ }^{1} 8$ Lickona state tht "we arrive at the natural moral law through reason and experience" (27). But this is not my goal here. The concern, here, is the immediate experience of the learner within the direct relationship between her faith/value and reality of the situation in which she is dealing with. This spare-of-the-moment consciounsous construction of knowledge and value is at stake here.

${ }^{19}$ I realize that while Western educators see Islam mainly as rituals without understanding its theological principles, and religious education as moral education, Muslims often discuss these issues at the ideal level without relating them to the realities of their practices. Yet, it is necessary to see that all these educators are equally missing the problem here.

${ }^{20}$ Allen Lockwood questions if "we can really instill such characters, as these are unintentional values." I may agree with him at addressing intentiality as important, but this is not the problem here. 
${ }^{21}$ See the various perspectives, such as Nord (1995: 233) and Gaddy, et al. (1996:199203) on the value and details of the content of the document and, the names and aliance of the seventeen national religious and educational organizations who cosponsored the curriculum, including the Islamic Society of North America that was the only Islamic organization represented.

${ }^{22}$ See Barazangi's (in review) discussion of Muslim women's self-identity ; and (1996) for further details on Islamic Identity and gender justice.

${ }^{23}$ Noddings (1993) suggestion that teachers be pedagogically neutrual is problematic because this is not possible once each teacher realizes his or her identity and moral autonomy.

${ }^{2} 4$ See, for instance, Nord's (1995:104) quotation of John Leland comparing Juesus to Muhammad in the context of imposing certain belief and practice. Had Nord took the extra step himself to study Islam, he would not have used such a biased quote concerning the use of the sord in "Muhammadan" tradition from a secondary source to make his point.

${ }^{25}$ See, for example, the views expressed in some orientalists literature, and some of the responses by Muslim clergy to issues of Muslim women's human rights that are often quoted out of contexts .

${ }^{26}$ See, for example, Dr. Henry Jordan's statement (fn 11), and the responses to it in The Minaret (July/Aug, 1997), The Washington Report and ADC Times ( August/September,1997).

${ }^{27}$ In addition to being prevented from co-ed physical education and social activities, while their brothers often left to participate in similar activities that makes these girls wonder as to whether or not they want to identify with Islam, Muslim women in the US, and other places, are prevented from attending Friday Prayers or are being asked to pray in a separate, segregated buildings just as slaves or blacks used to be treated before the civil right movement. Furthermore, they hardly are represented in Muslim organizations consultative bodies that make community decisons even when these women constitute the majority of education practioners and community volunteer workers. 


\section{REFERENCES}

Anderson, Christopher, Patricia G. Avery, Patricia V. Pederson, Elizabeth S. Smith, John L. Sulivan. 1997. "Divergent Perspectives on Citizenship Education: A QMethod Study and Survey of Social Studies Teachers." American Educational Research Journal, vo.34, no.2, Summer 1997: 333-364.

Baier, Annetta C. 1997. The Commons of the Mind. Chicago, Open Court: (65-76).

Barazangi, Nimat Hafez "Muslim Women's Islamic Higher Learning as a Human Right: Theory and Practice" in forthcoming Gisela Webb, ed. 1998. Windows of Faith: Muslim women Scholarship-Activisim in the united States. Syracuse University.

Barazangi, Nimat Hafez. 1997. Muslim Women's Islamic Higher Learning as a Human Right: Action Plan. In Erika Loeffler Friedl and Mahnaz Afkhami, eds. Politics of Participation: Muslim Women and the Beijing Platform.Syracuse: Syracuse University.

Barazangi, Nimat Hafez. 1996. Vicegerency and Gender Justice, in Nimat Hafez Barazangi, et al., eds. Islamic Identity and the Struggle for Justice. Gainesville, University Press of Florida. pp. 77-94.

Barazangi, Nimat Hafez. 1995. Religious Education. The Oxford Encyclopedia of the Modern Islamic World. John L. Esposito, Ed. New York: Oxford University Press, Vo. I: 406:411.

Barazangi, Nimat Hafez 1993. Worldview, Meaningful Learning and Pluralistic Education: The Islamic Perspective. Religion and Public Education (now, Rleigion and Education), Vo. 20, No. 1, 2, 3, pp. 84-98.

Bennett, William John. 1992. The De-Valuing of America: the Fight for our Culture and our Children. New York, Summit Books. 
DeVries, Rita. 1997. Piaget's Social Theory. Educational Researcher, vo. 26, no.2, March 1997: 4-17.

Donmoyer, Robert. 1997. Revisiting the "Talking 'Truth' to Power" problem. Educational Researcher..vo. 26, no.3, April, 1997:2.

Gaddy, Barbara B., T. William Hall, Robert J. Marzano. 1996. School Wars: Resolving Our Conflicts Over Religion and Values. San Francisco, Jossey-Bass.

Glazer, Nathan. 1977. "Multiculturalism Gains an Unlikely Supporter." The Chronicle of Higher Education. Aprill 11, 1997: A 16, A18.

Glazer, Nathan. 1997a. "Multiculturalism, Religious Conservatism, and American Diversity." In Martin E. Marty, and Scott Appleby, eds. Religion, Ethnicity, and Self Identity. Hanover, University Press of New England: 125-141.

Hare, R. M. 1997. Essays on Religion and Education. Clarendon, Oxford.

Hollinger, David. A. 1997. "Visiting Historian to Discuss culture and Ethnoracial Classifications." Cornell Chronicle, April 24, 1997: 4.

Hollinger, David. A. 1996. Science, Jews, and Secular Culture: Studies in MidTwentieth-Century American Intellectual History. Princeton University: (17).

Lickona, Thomas. 1997. "The Promulgation of Virtue" in Anne Turnbaugh Lockwood, ed. Conversation with Education Leaders: Contemporary Viewpoints on Education in America. New York, State University of New York: 21-30.

Lockwood, Alan L. 1997. "The Current Incarnation of Character" in Anne Turnbaugh Lockwood, ed. Conversation with Education Leaders:: 31-38. 
Nord, Warren. A. 1995. Religion and American Education: Rethinking a National Dilemma. Chapel Hill, The Univ. Of North Carolina Press.

Noddings, Nel. 1993. Educating for Intelligent Belief or Unbelief. New York: Teachers College, Columbia University.

Rahman, Fazlur. 1980. Major Themes of the Qur'an. Minneapolis: Bibliotheca Islamica.

Shapiro, June, Sylvia Kramer, Cathreine Hunerberg. 1981. Equal Their Chances:

Children's Activities for Non-sexist Learning. Englewood Cliff: Prentice Hall.

Sullivan, William. 1982. Reconstructing public Philosophy. Berkeley: University of California (10-19). 
i I would like to acknowledge Mohja Kahf and Nobl Barazangi for their invaluable insights and comments.

ii See the distinction between Islamic and Muslim education in Barazangi (1995) and (1997). Islamic education, referred to in the Qur'an (3:110) as thr process of shaping character within the Islamic worldview, requires the exposition to all knowledge as a means to understanding the parameters set in the Qur'an for a constructive relationship with God, other human beings, and nature.

iii Integration indicates the ability to maintain the Islamic belief system at its central level, Tawhid (Oneness of God and humanity) and to objectify it in the Western secular environment. See further explanation in Nimat Hafez Barazangi. The Education of North American Muslim Parents and Children. 1990. The American Journal of Islamic Social Sciences. vol. 7, no.3: 385-402.

iv In a data-base search on Religion and education I found only six references out of 450 related to Islam, and none of them is concerned with American Muslims. There are several publications known to me as an educator, but for some reason, they are not being indexed by "mainstream" bibliography. The recent efforts of the Council on Islamic Education with regards to world history in textbooks (Teaching about Islam \& Muslims in the Public School Classroom, 1995; and Strategies and Structures for Presenting World history, 1994) are the most recognized among mainstream educators, but was not indexed either. ${ }^{v}$ See, for example, Khaliijah Mohammad Salleh. The Role of Men and Women in Society. Islamic Horizons, January/February, 1997:57.; Syed Ali Ashraf (New Horizons in Muslim Education. Cambridge Univ. Press, 1995); Anis Ahmad. 1984. Muslim Women and Higher Education: A Case for Separate Institutions for women. Islamabad, Pakistan.

${ }^{\text {vi }}$ See for example, Jamila Al-Hashimi "Public School System Versus Islamic School" (Islamic Horizon, June/July 1997: 55) in which she reason that the public schools decline is the result of their attempt to make "the school increasingly the carrier of all kinds of social policies" instead of doing its job "to teach children elementary knowlesge skills". In the same breath, she states that "religious groups, in general, have a head start on teaching values in school." It is exactly this dichotomy in education that is creating problems in our educational system. See another type of dichoromy in R. M. Hare's (Essays on Religion and Education, oxford Univ. Press, 1992) discussion of Wilson (1964) distinction between the method and the content of education vis-a'-vis indoctrination (113-130).

vii See Nimat Hafez Barazangi forthcoming "Islamic HigherLearning as a Human Right: Theory and Practice" in Gisela Webb, ed. 1998. Windows of Faith; and "Vicegerency and Gender Justice" in Barazangi, et al. eds. Islamic Identity and the Struggle for Justice. University Pres of Florida, 1996: 77-94.

viii See details of the distinctions between "Islamic education," "Muslim education" and Western, secular education/universal schooling in Nimat Hafez Barazangi, 1995. "Religious Education."

${ }^{i x}$ Deborah Mayo-Jefferies. 1994. Religious Freedon in the Education Process: A Research Guide to Religion in Education (1950-1992). Buffalo: William S. Hein ( ix).

${ }^{x}$ For example, the recent degrading remarks of Dr. Jordan. (see note 11)

${ }^{x i}$ Dr. Jordan said in the heated argument about placing the plate of the Ten Commandments in schools: "screw the Budhists and kill the Muslims." May 12, 1997 as reproted by the Associate Press. His statement indicates exactly the point that I am emphasizing. That is, our pluralism has not become cognitively and morally autonomous. Individuals are still struggling between their normative beliefs and the "rational" presentation of others' beliefs. They have not yet come to a point where they autonomously are able to integrate the two views, or make sense of them within their own frame of reference. Whether the reason is ignorance or pure refusal to accept the other's norms is a matter for educators to assess. But the results are still strikingly suggestive that unless such individuals are able to understand and undertake cognitive egalitarism on their own, any attempt of having them accept social egalitarism will contiue to have a weak point in the system and is apt to backlash with the change of circumstances.

xii Arjomand, Said Amir, ed. 1993. The Political Dimensions of Religion. State University of New york Press. (P.4)

xiii See my forthcoming article "Between the Post-ethnic and the Unique: Exclusion of American Muslim Women from Decison-Making" (in review).

xiv I use "Western," "Islamic," "Muslim," "pluralistic", and other expressions in quotes because I want to draw attention to the elusiveness of these expressions, especially when contrasting "Islamic" in reference to religion vs. "Western" in reference to geogrpahy. 
${ }^{x v}$ See Rheta DeVreis. Piaget's Social Theory.” Educational Researcher, vo. 26, no.2, march 1997:4-18, for further explanation of Piaget's differentiation of autonomous vs heteronomous morality.

xvi Andrea Lueg. "The Perception of Islam in Western Debate." In Jochen Hippler and Andrea Lueg, eds. 1995. The Next Threat:Western Perception of Islam. Translated by Laila Friese. Boulder: Pluto Press: 16

xvii Note that I intentially am using the terms "character", "moral", and "religious" upbringing interchangebly in order to bring the focus to my claim that the problem is in our framework of understanding of character, moral and religious pedagogy within the framework of "secular, pluralistic" education . I do agreee with some of the distinctions that Alan Lockwood or Lickona present, but I do no see these distinctions as the core of the problem here.

xviii Lickona state tht "we arrive at the natural moral law through reason and experience" (27). But this is not my goal here. The concern, here, is the immediate experience of the learner within the direct relationship between her faith/value and reality of the situation in which she is dealing with. This spare-ofthe-moment consciounsous construction of knowledge and value is at stake here.

${ }^{x i x}$ I realize that while Western educators see Islam mainly as rituals without understanding its theological principles, and religious education as moral education, Muslims often discuss these issues at the ideal level without relating them to the realities of their practices. Yet, it is necessary to see that all these educators are equally missing the problem here.

${ }^{\mathrm{xx}}$ Allen Lockwood questions if "we can really instill such characters, as these are unintentional values." I may agree with him at addressing intentiality as important, but this is not the problem here.

${ }^{x x i}$ See the various perspectives, such as Nord (1995: 233) and Gaddy, et al. (1996:199-203) on the value and details of the content of the document and, the names and aliance of the seventeen national religious and educational organizations who cosponsored the curriculum, including the Islamic Society of North America that was the only Islamic organization represented.

xxii See Barazangi's (in review) discussion of Muslim women's self-identity ; and (1996) for further details on Islamic Identity and gender justice.

xxiii Noddings (1993) suggestion that teachers be pedagogically neutrual is problematic because this is not possible once each teacher realizes his or her identity and moral autonomy.

xxiv See, for instance, Nord's (1995:104) quotation of John Leland comparing Juesus to Muhammad in the context of imposing certain belief and practice. Had Nord took the extra step himself to study Islam, he would not have used such a biased quote concerning the use of the sord in "Muhammadan" tradition from a secondary source to make his point.

${ }^{x x v}$ See, for example, the views expressed in some orientalists literature, and some of the responses by Muslim clergy to issues of Muslim women's human rights that are often quoted out of contexts .

${ }^{x x v i}$ See, for example, Dr. Henry Jordan's statement (fn 11), and the responses to it in The Minaret (July/Aug, 1997), The Washington Report and ADC Times ( August/September,1997).

xxvii In addition to being prevented from co-ed physical education and social activities, while their brothers often left to participate in similar activities that makes these girls wonder as to whether or not they want to identify with Islam, Muslim women in the US, and other places, are prevented from attending Friday Prayers or are being asked to pray in a separate, segregated buildings just as slaves or blacks used to be treated before the civil right movement. Furthermore, they hardly are represented in Muslim organizations consultative bodies that make community decisons even when these women constitute the majority of education practioners and community volunteer workers. 